\title{
ЧАСТИНОМОВНИЙ СТАТУС НЕВІДМІНЮВАНИХ СЛІВ У СУЧАСНОМУ МОВОЗНАВСТВІ
}

Кавера Н. В. Частиномовний статус невідмінюваних слів у сучасному мовознавстві.

У статті розкрито дискусійність проблеми частиномовного статусу невідмінюваних слів зі значенням стану в сучасному мовознавстві, проаналізовано різні концепції встановлення їхньої морфологічної природи, з'ясовано термінологію найменування таких слів.

Ключові слова: предикативний прислівник, невідмінюване слово, аналітичне дієслово, предикат стану.

Кавера Н. В. Лингвистический статус несклоняемых слов в современном языкознании.

В статье раскрыта дискуссионность проблемы лингвистического статуса несклоняемых слов с семантикой состояния в современном языкознании, проанализированы разные концепции определения их морфологической природы, установлена терминология наименования таких слов.

Ключевые слова: предикативное наречие, несклоняемое слово, аналитический глагол, предикат состояния.

Kavera N. V. Morphological status of indeclinable words in modern linguistics.

The article focuses on the debatable problem of morphological status of the indeclinable words with stative meaning in modern linguistics. Different conceptions of defining their morphological nature are analyzed. Terminology for classifying these words is found out.

Key words: predicative adverb, indeclinable word, analytical verb, predicate of state.

У сучасному мовознавстві досі немає загальноприйнятої думки про частиномовну природу невідмінюваних слів із семантикою стану, а також єдиної термінології щодо їх найменування. Одна група вчених [23; $12 ; 2$; 9; 14; 8; 6] виділила їх в окрему частину мови і кваліфікувала як «слова категорії стану» [2, с. 334; 12, с. 279; 14, с. 56], «предикативи» [9, с. 359], «безособово-предикативні слова» [5, с. 278], «станівник» [6, с. 237].

Думку про частиномовний статус невідмінюваних слів на позначення фізичного, психічного, інтелектуального стану особи та станів довкілля в російському мовознавстві вперше висловив Л.В. Щерба у статті «О частях речи в русском языке» (1928) [23, с. 74-76]. Він уважав, що ці слова в поєднанні зі зв'язкою не є ні повними прикметниками, ні іменниками в називному відмінку. Вони виражені або незмінюваною формою (холодно, тепло), або формою іменника $з$ прийменником (без памяти), або формами з родовими закінченнями: нуль для чоловічого роду, -а для жіночого роду (пора), -о, -е, (искренне) для середнього роду, або формою іменника в орудному відмінку (замужем) [23, с. 75-76].

Учення про нову частину мови, що активно розвивається в російській 
мові, або слова категорії стану, розвинув В. В. Виноградов. 3 приводу цієї частини мови він писав: «Причиною розвитку та поширення категорії стану $\epsilon$ суперечності між морфологічними та синтаксичними функціями імен. Морфологічно та семантично ім'я протиставляється дієслову, а синтаксично ім'я також може бути присудком, як і дієслово. Однак ім'я в російській мові не може набути основних семантичних властивостей дієслова, навіть якщо воно вживається тільки як присудок. Тому в системі мови виникає граматична та семантична диференціація між формами дій, процесів, що відбуваються в часі та мають мінливі й різноманітні відтінки просторовочасового характеру... та між формами якісних станів, у яких опиняються особи та предмети чи особи з предметами. Проте, звісно, складна і тонко розвинена система дієслова з його категоріями особи, часу та дієвідмінювання, 3 його різноманітними формами керування повинна була здійснити величезний організаційний вплив на нову категорію стану» [2, с. 334]. За його визначенням, до слів категорії стану належать «невідмінювано-іменні та прислівникові слова, що мають форми часу (для минулого та майбутнього часу аналітичні, утворені за допомогою приєднання відповідних форм зв'язки бути) і вживаються тільки у функції присудка... Природно, що і значення предмета, й ознаки чи ознако-обставинні відношення абсолютно є чужими для категорії стану. Слова, що належать до категорії стану, виражають «недійовий» стан, який може уявлятися безособово (досадно, соромно) або належати тій чи тій особі як суб'єктові, що перебуває в цьому стані» [2, с. 332].

I. I. Мєщанінов, визнаючи слова категорії стану як особливу частину мови, як особливий пласт слів, уводить до іiі складу тільки нечленні форми прикметників і короткі форми дієприкметників активного стану, вилучаючи $з$ неї безособово-предикативні слова на -о [12, с. 279].

О.В. Ісаченко відзначає наявність в російській мові особливого граматичного класу слів, що виконують тільки функцію присудка, відірвались від своїх основних парадигм та набули особливих форм часу. Він розширює «категорію стану» до поняття «предикатива», зарахувавши до цього лексико-граматичного розряду слів не тільки модальні предикативи (надо, можно, нельзя, (я) должен, (я) намерен), іменникові предикативи (пора, жаль), предикативи стану і чуттєвого сприймання (стьлдно, весело, видно), а й займенникові предикативи (никого, ничего, некогда) та предикативи наявності чого-небудь (есть, нет) [9, с. 358-362].

Усі згадані слова, справді, є предикативами, на думку М. С. Поспєлова, оскільки їм властива синтаксична функція присудка, проте вони не утворюють особливої частини мови, бо з огляду на граматичне вчення про слово не мають морфологічних ознак, що об'єднують їх і диференціюють від займенників, прислівників та дієслів. Слова категорії стану становлять окрему частину мови через властиві їм специфічні аналітичні форми вираження граматичних категорій часу та способу, а не тому, що виступають у синтаксичній () Н. В. Кавера, 2013. 
функції присудка. Вони є не предикативними словами, а безособовопредикативними словами, які можуть вживатися або безсуб'єктно, або 3 давальним суб'єкта, що виступає конструктивно необхідним додатком, або з інфінітивом, що виражає дію, приписувану суб'єкту [14, с. 56-57].

На зближенні слів категорії стану 3 дієсловами на основі їхньої постійної предикативної синтаксичної функції та здатності керувати знахідним і родовим відмінками акцентувала увагу С.М. Галкіна-Федорук, проте, використовуючи термін «безособово-предикативні слова», вона зауважувала, що «не досить чіткі, але вже помітні ознаки в групі слів, семантично однорідних, виокремлюють їх в якусь нову, поки що не зовсім сформовану частину мови, але настільки відмінну від прислівників, що зараховувати іiі до категорії прислівників неможливо. Перешкоджає цьому приєднанню і відмінність у значенні, і абсолютно інші синтаксичні функції, i граматичні зв'язки, і співвіднесеність з частинами мови» [5, с. 278].

Не заперечують існування слів категорії стану як окремої частини мови й автори праці «Современный русский язык» за редакцією В. А. Бєлошапкової. Цей морфологічний клас слів формують тільки незмінні повнозначні слова можно, нужно, жаль, єдиною синтаксичною функцією яких є функція присудка. Лексеми на зразок светло, грустно, весело, що здатні виконувати вказану функцію і функцію присудка, вважають прислівниками [16, с. 520].

Як невідмінювану частину мови, що охоплює слова із семантикою різних станів і виконує роль головного члена в безособовому реченні, тлумачать слова категорії стану в «Курсі сучасної української літературної мови» М. А. Жовтобрюха і Б. М. Кулика [8, с. 335]. Термін «присудкові слова» або «незмінні безособово-предикативні слова» знаходимо в «Курсі сучасної української літературної мови» за редакцією Л. А. Булаховського [10, с. 318].

Як самостійну частину мови слова категорії стану кваліфікує В. О. Горпинич, використовуючи для iї називання термін «станівник». За його визначенням, станівник - «клас невідмінюваних слів із категорійним значенням непроцесуального стану у функції головного члена (присудка) односкладних (безособових) речень» [6, с. 237]. Він стверджує, що значення непроцесуального стану $\epsilon$ семантичною базою, на якій формується станівник як частина мови, невідмінюваність - його морфологічною ознакою, а синтаксичною функцією та диференційною ознакою, яка розмежовує станівники й інші частини мови, - функція головного члена односкладного речення [6, с. 237].

Інша група мовознавців $[22 ; 20 ; 21 ; 11 ; 1 ; 3]$ категорично спростовує частиномовний статус слів категорії стану на тій підставі, що вони не протиставлені іншим класам слів ні за своєю семантикою, ні за набором морфологічних категорій, ні за синтаксичною роллю. Так, А. Б. Шапіро писав, що в системі класів слів сучасної російської мови місця для категорії стану немає, оскільки слова категорії стану не мають яскравих 
морфологічних показників, які б відрізняли їх від слів інших частин мови. Вживання їх в функції присудка - ознака синтаксична. Однієї цієї ознаки недостатньо для визначення частини мови, до якої належить слово. До речі, спостереження над історичними фактами свідчать про те, що всі ті форми 3 їхніми присудковими функціями, які вводять до категорії стану Л.В. Щерба та В.В. Виноградов, здавна існують у російській мові й жодних принципово нових явищ у цій сфері не відбувається [22, с. 49-51]. Він уважає лексеми на зразок холодно, сухо, светло, хорошо, плохо, красиво, жалко, обидно, тревожно, опасно прислівниками із семантикою якісного стану, а слова жаль, надо, можно, нельзя «безпритульними», тобто одиницями, які не можна зарахувати до жодного $з$ наявних морфологічних класів [22, с. 53-54].

Фр. Травничек підкреслював, що слова категорії стану в російській мові не утворюють єдиної та однорідної групи за семантикою: одні лексеми виражають почуття (грустно, противно, бодро, приятно), інші поняття про загальні властивості предметів і явищ (понятно, ясно). Те, що слова категорії стану не узгоджуються і не керуються, - цілком природний наслідок їхньої функції в реченні, а не є особливістю саме цих слів, бо те саме ми бачимо i в інших бездієслівних i дієслівних односкладних реченнях на зразок Пустяки; Морозит тощо. Він робить висновок про те, що ці слова не мають жодної ознаки, яка відрізняла б їх від інших частин мови настільки, щоб можна було вважати «безособовопредикативні слова» на -о особливою частиною мови [20, с. 47-50].

В. О. Трофимов стверджував, що «категорія стану є однією 3 можливих функцій частин мови... Категорія стану може одержати вираження в будьякій повнозначній частині мови: он беспокоится (дієслово); он обеспокоен, она взволнована (прикметник); она в волнении (іменник у прийменниковій сполуці); ему неспокойно (прислівник)... В усіх присудках природно $є$ категорія часу. Немає ніяких підстав виокремлювати 3 цього ряду тільки іменні (за ознакою невідмінюваності) i безособово-предикативні (за ознакою нездатності до якісного або обставинного зв'язку 3 дієсловом) слова. I невідмінюваність і нездатність до зв'язку з дієсловом - природна належність присудка: у першому разі це викликане узгодженням у називному відмінку 3 особою-діячем, у другому - це зумовлено самостійністю ролі головного члена» [21, с. 254].

I. К. Кучеренко зазначав: «Стан - це не що інше, як одна 3 наявних ознак предметів i явищ. Вона усвідомлюється як один 3 аспектів емоційно-вольового змісту людської психіки. Через це й передається словесними засобами як реакція людського організму - його переживання, тобто усвідомлюється в почуттях, сприйманнях, відчуттях $\mathrm{i}$ через них, наприклад: соромно, весело, шкода і т.д. Ознака стану належна чомусь або комусь. ...вона становить суть змісту присудка (c) Н. В. Кавера, 2013. 
двочленного речення... або одночленного...» [11, с. 123].

С. П. Бевзенко указував на те, що слова категорії стану мають низку ознак, на підставі яких їх можна об’єднувати в одну групу. Цими ознаками є однакова синтаксична функція і незмінна форма. Приблизно однаково («аналітично») вони «творять» «форми» часу, однак значення часу вони самі по собі не мають, а отримують завдяки допоміжному дієслову. Незважаючи на це, склад їх в українській (як і в російській) мові досить строкатий, а граматичні ознаки не виразні і «...навряд чи $\epsilon$ необхідність розглядати ці слова як окремий морфологічний клас слів, окрему частину мови в українській, а також у російській i iнших слов'янських мовах. Абсолютна більшість слів «категорії стану» може розглядатися, як це й робиться звичайно, як специфічна група прислівників, т. зв. предикативні прислівники...» [1, с. 187].

Потрібно також зазначити, що в українському мовознавстві відома спроба на підставі семантики та присудкової функції виокремити предикативні слова в особливий розряд предикативних прислівників, розподіливши їх на предикативні (безлюдно, важливо, вітряно, видно, сніжно, можна, морозно, треба, потрібно, навздогад, простимо, властиво, чутно, сумнівно, ліньки, досадно, жалко, корисно, соромно, необхідно, варто (варт) та ін.), атрибутивно-предикативні (безмовно, безпечно, біло, боляче, мало, цікаво, близько, помітно, спокійно, легко, приємно, весело, смішно, вільно, икідливо, вигідно, німо, високо, нудно, гидко, глухо, голо, незручно, гірко, пізно, сумно, брудно, далеко, дико, погано тощо) та предикативно-модальні (відомо, можливо та ін.) [17, с. 431-432].

В інших академічних мовознавчих працях слова категорії стану також влито до прислівників i розглянуто як окрему групу за синтаксичними функціями $[18$, с. $290 ; 19$, с. $405 ; 7$, с. $309 ; 15$, с. 705]. Так, лексеми, що виступають у ролі головного члена безособових речень та виражають відношення до особи, яка зазнає певного стану, або вказують на загальний фізичний стан природи, визначені як безособово-предикативні прислівники $[18$, с. 290]. Предикативні прислівники окреслюють у межах якісних прислівників і характеризують як одиниці, що передають стан, - суб'єктний або безсуб'єктний, причому значення стану зближує їх 3 короткими формами прикметників та пасивних дієприкметників [15, с. 705].

Думку про неможливість уважати предикативні слова прислівниками чи словами категорії стану висловив В.М. Мігирін. За його словами, форми, що виступають у позиції головного члена односкладного речення й омонімічні 3 короткими прикметниками і прислівниками на -о, -е (легко, тяжело, весело, далеко, тихо), являють собою розряд безсуб'єктних прикметників. Свою теорію він підтвердив такими аргументами: основна функція прислівника виражати обставину, основна функція короткого прикметника - виражати присудок; багато прикметників керує відмінками, для прислівників керування 
відмінками не типове; прикметники можуть сполучатися із суб'єктним інфінітивом, прислівники - ні; серед безсуб'єктних прикметників є слова, що мають паралелі тільки прикметникові й позбавлені подібних прислівникових (известно, невероятно, возможно, безопасно, свойственно, досадно, скользко, готово, напр.: Днище лодки скользко - Под ногами скользко - немає прислівника скользко); усі безсуб'єктні прикметники мають відповідники як прислівникові, так і прикметникові, напр.: Море спокойно - На душе спокойно - Говорил спокойно [13, с. 152].

Предикативні прислівники та невідмінювано-іменні слова зі значенням стану I. Р. Вихованець уводить до зони дієслів стану й визначає їх як аналітичні дієслова стану [3, с. 120-122; 4, с. 294-295], аргументуючи цей статус тим, що вони:

1. Не мають самостійного індивідуального категорійного значення, що характерне для частин мови, а лише виражають властиві дієслову стани.

2. Дублюють морфологічні категорії часу і способу дієслова, але граматичні значення згаданих категорій на противагу власне-дієсловам виражені тільки аналітично, тобто за допомогою форм морфеми-зв'язки бути та напівзв'язок ставати, стати, робитися, зробитися та ін.: Надворі тепло; Надворі буде (стане) тепло; Надворі було (стало, зробилося) тепло; Надворі було б тепло; Хай (нехай) буде тепло. Щодо дієслівних категорій особи та числа, то вони є одноособовими, бо не формують особово-числових протиставлень, а тільки вказують на третю особу однини. Граматична категорія виду в цих слів нівельована.

3. Як і власне-дієслова, виконують функцію співвідносного з присудком головного члена односкладного речення, або, поєднуючись переважно 3 інфінітивом, утворюють складений інфінітивний головний член односкладного інфінітивного речення, який, окрім значення стану, має семантику потенційної дії.

Отже, невідмінювані слова не утворюють нової частини мови, а $\epsilon$ аналітичними дієсловами із семантикою стану, за якими закріплена одноособовість і нерозчленована категорія виду. Вони формують ядро відприслівникових дериватів-предикатів стану.

\section{Література}

1. Бевзенко С. П. До питання про «категорію стану» як окрему частину мови в українській мові / С. П. Бевзенко // Наукові записки Ужгородського університету. Т. XXXVII. Філологія. - 1959. - С. 183-187.

2. Виноградов В. В. Русский язик: (Грамматическое учение о слове) : [учеб. пособ.] / В. В. Виноградов. - М. : Высшая шк., 1986. -639 с.

3. Вихованець I. Р. Частини мови в семантико-граматичному аспекті / І. Р. Вихованець ; Інститут мовознавства імені О. О. Потебні АН УРСР. - К. : Наук. думка, 1988. $-256 \mathrm{c.}$

4. Вихованець I. Р. Теоретична морфологія української мови : [академ. граматика укр. мови] / І. Вихованець, К. Городенська ; за ред. І. Вихованця. - К. : Унів. вид-во «Пульсари», 2004. - 398 с. 
5. Галкина-Федорук Е. М. Безличные предложения в современном русском языке /

Е. М. Галкина-Федорук. - М. : Изд-во Моск. ун-та, 1958. - 332 с.

6. Горпинич В. О. Морфологія української мови : [підручн.] / В. О. Горпинич. К. : Академія, 2004. - 336 с.

7. Грамматика современного русского литературного языка / [отв. ред. Н. Ю. Шведова] ; Институт русского языка АН СССР. - М. : Наука, 1970. - 767 с.

8. Жовтобрюх М. А. Курс сучасної української літературної мови / М. А. Жовтобрюх, Б. М. Кулик. - К. : Рад. школа, 1965. - Ч. 1. - 422 с.

9. Исаченко А. В. Грамматический строй русского языка в сопоставлении с словацким. Морфология / А. В. Исаченко. - Братислава : Изд-во Словацкой академии наук, 1954. - Ч. 1. - 387 с.

10. Курс сучасної української літературної мови / за ред. Л. А. Булаховського. К. : Рад. школа, 1951. - Т. 1. - 519 с.

11. Кучеренко I. К. Теоретичні питання граматики української мови. Морфологія / І. К. Кучеренко. - К. : Вид-во Київського ун-ту, 1964. - Ч. 2. - 159 с.

12. Мещанинов И. И. Члены предложения и части речи / И. И. Мещанинов. - М.Л. : Изд-во Академии наук СССР, 1945. - 322 с.

13. Мигирин В. Н. Категория состояния или бессубъектные прилагательные? / В. Н. Мигирин // Исследования по современному русскому языку. - М. : Изд-во Москов. ун-та, 1970. - С. 150-157.

14. Поспелов Н. С. В защиту категории состояния / Н. С. Поспелов // Вопросы языкознания. - 1955. - №2. - С. 55-65.

15. Русская граматика : в 2 т. - М. : Наука, 1980. - Т. 1 : Фонетика. Фонология. Ударение. Интонация. Словообразование. Морфология. - $783 \mathrm{c.}$

16. Современный русский язик : [учеб.] / под ред. В. А. Белошапковой. - М. : Высшая шк., 1989. - 800 с.

17. Сучасна українська літературна мова / за заг. ред. акад. АН УРСР І. К. Білодіда. Кн. 2. Морфологія. - К. : Наук. думка, 1969. - 583 с.

18. Сучасна українська літературна мова : [підруч.] / [М. Я. Плющ, С. П. Бевзенко, Н. Я. Грипас та ін.] ; за ред. М. Я. Плющ. - К. : Вища шк., 1994. - 414 с.

19. Сучасна українська літературна мова : [підруч.] / [А. П. Грищенко, Л. І. Мацько, М. Я. Плющ та ін.] ; за ред. А. П. Грищенка. - К. : Вища шк., 2002. - 439 с.

20. Травничек Фр. Заметки о «категории состояния»/ Фр. Травничек // Вопросы языкознания. - 1956. - № 3. - С. 46-53.

21. Трофимов В. А. Современный русский литературный язык. Морфология / В. А. Трофимов. - Л. : Изд-во ЛГУ, 1957. - 280 с.

22. Шапиро А. Б. Есть ли в русском языке категория состояния как часть речи? / А. Б. Шапиро // Вопросы языкознания. - 1955. - № 2. - С. 42-54.

23. Щерба Л. В. О частях речи в русском языке / Л. В. Щерба // Избранные работы по русскому языку. - М. : Учпедгиз, 1957. - 188 с. 